\title{
A diabetes, a stressz és az alvásproblémák kapcsolata a Hungarostudy 2013 kutatás adatainak fényében
}

\author{
Vincze Ágnes ${ }^{1}$ - Kertész Laura eh. ${ }^{2}$. Czeglédi Edit dr. ${ }^{3}$ \\ ${ }^{1}$ Semmelweis Egyetem, Általános Orvostudományi Kar, I. Belgyógyászati Klinika, Budapest \\ ${ }^{2}$ ELTE Eötvös Loránd Tudományegyetem, Pedagógiai és Pszichológiai Kar, Budapest \\ ${ }^{3}$ Semmelweis Egyetem, Általános Orvostudományi Kar, Magatartástudományi Intézet, Budapest
}

\begin{abstract}
Bevezetés: A cukorbetegség világméretú problémája hazánkban is egyre súlyosabb népegészségügyi kérdéseket vet fel. Az elsődleges okaként megjelölt elhízásról az utóbbi években a civilizációs ártalmak komplex megértésére terelődött a hangsúly: felmerült és igazolódott az alvásproblémák és a stressz szerepe a betegség kialakulásában és az állapot súlyosbodásában.

Célkitüzés: A vizsgálat célja a stressz, az alvásproblémák és a diabetes összefüggéseinek vizsgálata a reprezentatív Hungarostudy 2013 kutatás mintáján.

Módszer: A keresztmetszeti kérdőíves vizsgálatban 2000 felnőtt vett részt. Átlagéletkor: 46,9 (SD = 18,24) év. BMIátlag: 26,0 (SD = 4,97) kg/m². Méróeszközök: szociodemográfiai adatok, a kezelt cukorbetegség jelenlétére vonatkozó kérdés, tünetlista, Észlelt Stressz Kérdőív.

Eredmények: Az adatfelvétel időpontját megelőző egy évben kezelt cukorbetegség előfordulási gyakorisága 8,2\%. A diabetesszel kezeltek észlelt stressz-szintje szignifikánsan magasabb, mint a cukorbetegséggel nem kezelteké $(\mathrm{t}(1944)=-2,586 ; \mathrm{p}=0,010)$. Az észlelt stressz a potenciális háttérváltozók kontrollja mellett tendenciaszintű kapcsolatot mutat a diabetesszel $(\mathrm{OR}=1,03 ; \mathrm{p}=0,052)$. Az elmúlt hónapra vonatkozóan alvással kapcsolatos problémák jelenlétéről a válaszadók 26,0\%-a, míg fáradtságról és energiahiányról a válaszadók 40,2\%-a számolt be. Az alvással kapcsolatos problémák jelenléte $\left(\chi^{2}(2)=61,108 ; p<0,001\right)$, és a fáradtság, illetve energiahiány érzése $\left(\chi^{2}(2)=51,061\right.$; $\mathrm{p}<0,001)$ egyaránt szignifikánsan gyakoribb a cukorbetegséggel élőknél. A kezelt cukorbetegség a potenciális háttérváltozók kontrollja mellett is előre jelzi az alvásproblémák $(\mathrm{OR}=1,77 ; \mathrm{p}=0,003)$, valamint a fáradtság és energiahiány $(\mathrm{OR}=1,88 ; \mathrm{p}=0,004)$ jelenlétét.

Következtetés: Eredményeink rámutatnak arra, hogy a világ más részein érvényesülő tendenciáknak megfelelően mind az alvásproblémáknak, mind a stressznek jelentős szerepe van a cukorbetegség alakulásában Magyarországon is. Mindez felhívja a figyelmet arra, hogy a nemzetközi protokolloknak megfelelően szükség lenne mind a cukorbetegség megelőzése, mind ellátása során ezen tényező́k hatékony szürésére és kezelésére.
\end{abstract}

Orv Hetil. 2019; 160(47): 1872-1880.

Kulcsszavak: cukorbetegség, stressz, alvás, alvásproblémák

\section{The relationship between diabetes, stress and sleep problems in the light of the Hungarostudy 2013 research data}

Introduction: The problem of diabetes worldwide raises increasingly serious public health issues in Hungary. In recent years, the emphasis on obesity as a primary cause of diabetes has been driven by a complex understanding of the causes of civilization: the role of sleep problems and stress in the development of the disease and the aggravation of the condition has been proven and supported.

Aim: The aim of the study was to investigate the relationship between stress, sleep problems and diabetes in the representative Hungarostudy 2013 survey.

Method: In the cross-sectional questionnaire study, 2000 adults participated. Mean of age was $46.9(\mathrm{SD}=18.24)$ years. The average BMI was $26.0(\mathrm{SD}=4.97) \mathrm{kg} / \mathrm{m}^{2}$. Measures: socio-demographic data, question about the presence of treated diabetes, symptomatic list, Perceived Stress Scale. 
Results: The frequency of diabetes treated one year before the date of the survey was $8.2 \%$. The levels of stress experienced by diabetic patients were significantly higher than those experienced by participants not treated with diabetes $(\mathrm{t}(1944)=-2.586, \mathrm{p}=0.010)$. After adjusting potential background variables, perceived stress shows a marginally significant relationship with diabetes $(\mathrm{OR}=1.03, \mathrm{p}=0.052) .26 .0 \%$ of the respondents reported sleep problems last month, while $40.2 \%$ of them reported fatigue and energy shortages. The presence of sleep problems $\left(\chi^{2}(2)=61.108\right.$, $\mathrm{p}<0.001)$ and feeling of fatigue or lack of energy $\left(\chi^{2}(2)=51.061, \mathrm{p}<0.001\right)$ are significantly more frequent among people with diabetes. Treated diabetes also predicts the presence of sleep problems $(\mathrm{OR}=1.77, \mathrm{p}=0.003)$ as well as fatigue and lack of energy $(\mathrm{OR}=1.88, \mathrm{p}=0.004)$ under the control of potential background variables.

Conclusion: Our results show that, according to trends in other parts of the world, both sleep problems and stress play a significant role in the development of diabetes in Hungary. This draws attention to the need for effective screening and treatment of these factors in the prevention and treatment of diabetes in accordance with international protocols.

Keywords: diabetes, stress, sleep, sleep problems

Vincze Á, Kertész L, Czeglédi E. [The relationship between diabetes, stress and sleep problems in the light of the Hungarostudy 2013 research data]. Orv Hetil. 2019; 160(47): 1872-1880.

(Beérkezett: 2019. július 2.; elfogadva: 2019. július 14.)

\section{Rövidítések}

$\mathrm{BMI}=($ body mass index $)$ testtömegindex $; \mathrm{CI}_{95}=(95 \%$ confidence interval) 95\%-os megbízhatósági intervallum; $\mathrm{HbA}_{\mathrm{lc}}=$ (glycated haemoglobin) glikált hemoglobin; HPA-tengely = (hypothalamic-pituitary-adrenal axis) hypothalamus-hypophysis-mellékvesekéreg-tengely; $\mathrm{OR}$ = (odds ratio) esélyhányados; $\mathrm{R}^{2}=$ (explained variance) megmagyarázott variancia $; \mathrm{RR}=$ (risk ratio) relatív kockázat; $\mathrm{SD}=$ (standard deviation) szórás

A cukorbetegség világméretű egészségügyi, gazdasági és össztársadalmi terhet jelent [1], prevalenciája évről évre nő hazánkban is. A 2002-es és 2012-es hazai reprezentatív felmérések adatai szerint a 2-es típusú diabetes arányának növekedése minden korábbi várakozást felülmúlt: 10 év alatt 6,2\%-ról 11,7\%-ra emelkedett, ami fóként a még munkaképes korú lakosságot érinti [2]. Mivel az életmóddal összefüggésben kialakuló 2-es típusú diabetes a cukorbetegség mintegy $90 \%$-áért felelős [3], a betegség megértéséhez hozzátartozik az életmódbeli tényezők vizsgálata és minél pontosabb feltérképezése.

Az utóbbi években számos vizsgálat igazolta, hogy az alvásnak nélkülözhetetlen szerepe van a metabolikus és hormonális folyamatok megfelelő alakulásában [4]. A közel 300 prospektív vizsgálat eredményét összefoglaló közlemények tanulsága szerint mind a 6 óránál kevesebb, mind a 9 óránál hosszabb napi alvásidő számottevő kardiometabolikus kockázattal jár, tehát az alvás és az egészségi állapot között már régóta feltétezett U-alakú összefüggés egyértelmúen igazolódott $[5,6]$. A rövid alvásidő (<6 óra/nap) a cukorbetegség $(\mathrm{RR}=1,37$; $\left.\mathrm{CI}_{95}: 1,22-1,53\right)$, az elhízás $\left(\mathrm{RR}=1,38 ; \mathrm{CI}_{95}: 1,25-\right.$ $1,53)$, illetve a bármely okból bekövetkező halálozás $\left(\mathrm{RR}=1,12 ; \mathrm{CI}_{95}: 1,08-1,16\right)$ relatív kockázatát egyaránt megnöveli [5]. Ugyanígy, a túl hosszú alvás (vagy ágyban töltött idő, $>9$ óra/nap) is növeli a diabetes $(R R=$
1,26; $\left.\mathrm{CI}_{95}: 1,11-1,43\right)$, az elhízás $\left(\mathrm{RR}=1,08 ; \mathrm{CI}_{95}\right.$ : $1,02-1,15)$ és általában a mortalitás $\left(\mathrm{RR}=1,39 ; \mathrm{CI}_{95}\right.$ : 1,31-1,47) rizikóját [6]. A túl hosszú alvásidő gyakran a rossz minőségú alvásnak, többnyire az alvás fragmentációjának a jele, amely miatt a hosszú alvásidő vagy csak hosszú ágyban töltött idő kompenzáció; illetve okozhatja kezeletlen betegség (tipikusan például obstruktív alvási apnoe) vagy eleve gyenge általános egészségi állapot is [7], így nem meglepó, hogy a hosszú alvásidő a rövid alvásidővel megközelítőleg azonos egészségi kockázattal jár.

A laboratóriumi körülmények között végzett kísérleti alvásmegvonás eredményei magyarázatot adnak arra, hogy az alváshiány milyen folyamatok mentén fokozza ilyen jelentős mértékben az elhízás és a 2-es típusú diabetes kockázatát [8]. Úgy túnik, hogy az alvásmegvonás három fó útvonalon keresztül befolyásolja közvetlen és közvetett módokon a metabolizmust. Egyrészt növeli a szimpatikus idegrendszeri aktivitást, aminek hatására feltehetően a melatoninfelszabadulás változásán keresztül csökken az inzulinszekréció, s ez inzulinrezisztenciához vezet. A szimpatikus idegrendszeri aktivitás fokozódása emellett hozzájárul a lipolízishez is: megnövekszik a plazmában keringő szabad zsírsavak szintje, aminek hatására nő az ektópiás zsír mennyisége a májban és az izmokban, ugyancsak fokozva az inzulinrezisztenciát [8]. Másrészt a HPA-tengely diszregulációján keresztül megemelkedik a nyál és a szérum kortizolszintje, így a szokásos esti kortizolszint-csökkenés nem következik be, emellett a proinflammatoricus citokinek és más gyulladásos markerek kismértékủ emelkedése révén enyhe gyulladás keletkezik a szervezetben [9], ami ugyancsak vezethet inzulinrezisztenciához. Harmadrészt alvásmegvonást követően megváltozik az étvágyszabályzó hormonok aránya, tehát az evést nem az energiaszükséglet határozza meg, hanem az étvágycsökkentő leptin csökkenése és az étvágyfokozó ghrelin növekedése révén nő a kalória- 


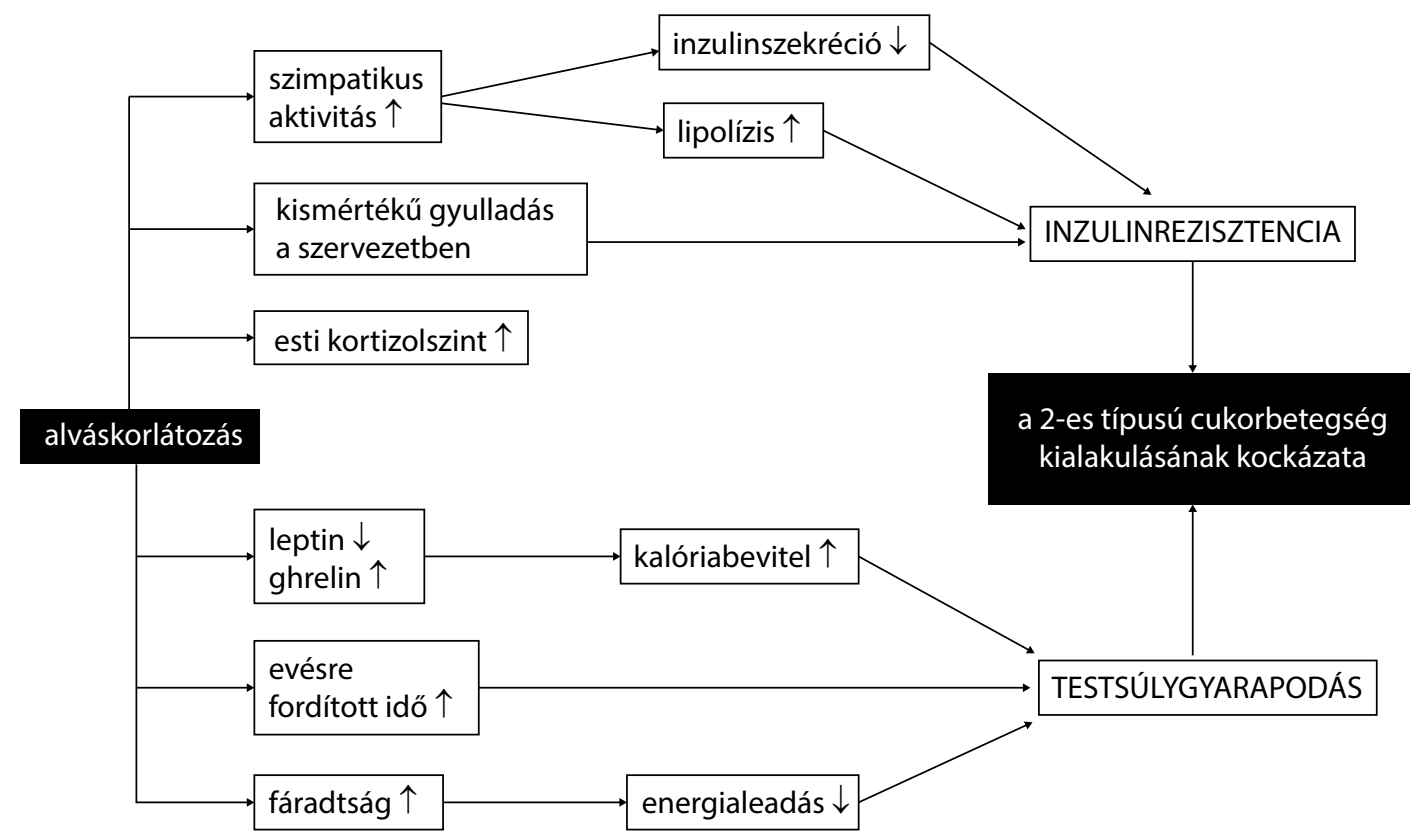

1. ábra $\quad$ Az alvásmegvonás hatása a metabolizmusra (Larcher és mtsai [8] 268. o. nyomán). Megjegyzés: A felfelé mutató nyilak növekedést, a lefelé mutató nyilak csökkenést jeleznek

bevitel, miközben az energialeadás változatlan marad, sőt alvásmegvonást követően jellemzően a fizikai aktivitás csökkenését is megfigyelték. A folyamatot az 1 ábra szemlélteti.

A fenti folyamat egészében kulcsfontosságú szerepet játszik a sötétség és a világosság napszaki változására érzékeny „belső központi óránk”, a hypothalamus suprachiasmaticus magjának eltolódott múködése. Egyre több időt töltünk munkával, mesterséges fényben - amely a természetes fényerőnek csak a töredékét biztosítja, így nem ad megfelelő fénymennyiséget a belső óra adekvát múködéséhez -, és egyre kevesebb időt töltünk alvással, ami a vázlatosan bemutatott, összetett mechanizmuson keresztül obesogen és diabetogen hatású [8]. A nem kielégítő alvás tehát a megváltozott társadalmi szokások, a munkaórák kitolódása miatt mindannyiunkat érint, ami mellett az egyénre jellemző szorongás mértéke, illetve az általános mentális állapot (amely gyakran szintén nem függetleníthető a társadalmi szokások alakulásától) ugyancsak az alvásminőség és -mennyiség változását okozhatja [10].

A krónikusan megemelkedett szorongásszint (alvásmegvonástól függetlenül is) hosszú távú kortizolszintemelkedéssel jár, ami pedig a fent részletezett - a megnövekedett szimpatikus idegrendszeri aktivitással, illetve HPA-tengely-diszregulációval járó - folyamatok révén növeli az abdominalis elhízás kockázatát [11]. Azok, akiknél genetikailag meghatározottan kifejezettebb a glükokortikoid-expresszió, és/vagy fokozottabb a glükokortikoid-szenzitivitás, egyfelől érzékenyebbek, sérülékenyebbek a mentális és fizikai stresszhatás iránt, másfelől esetükben a stressz még nagyobb szerepet játszhat az elhízás és ezen keresztül a 2-es típusú cukorbetegség kialakulásában [11].
A fentiek alapján teoretikusan összekapcsolhatóvá válik tehát a világméretű problémát jelentő elhízás, a cukorbetegség és az életmód- és életminőségbeli tényezőknek szintén a világ nagy részén bekövetkező változásai.

A már megállapított cukorbetegség alakulása jelentős mértékben az önmenedzsment függvénye [12], ezért azt mind a mentális állapot, mind az alvás befolyásolhatja, illetve esetenként a kettő interakciója is. Cukorbetegséggel élőknél a szubklinikus és a klinikailag jelentős szorongás és depresszió is magasabb arányú, mint az átlagpopulációban $[13,14]$. A nemzetközi adatokkal összhangban a cukorbetegséggel élők életminőség-mutatói hazánkban is rosszabbak a nem diabeteses populációhoz képest [15]. A romló mentális status pedig a krónikus betegek kezeléssel való együttmúködését és terápiahűségét közismerten negatívan befolyásolja [16].

A hosszú ideje fennálló, esetleg nem megfelelően kezelt cukorbetegség ugyancsak érinti az alvást és a pszichés állapotot egyaránt. A diabeteses perifériás neuropathia a cukorbetegek 26-47\%-ánál fordul elő, és e betegek megközelítőleg fele neuropathiás fájdalmat is tapasztal. A fájdalom állandó és intermittáló is lehet, egyeseknél az esti órákban és fizikai fáradtság esetében, illetve magasabb stressz-szint mellett erősebben jelentkezik. A fájdalom így negatívan érintheti az alvást, de maga a perifériás idegkárosodás kihat a mozgásra, a fizikai aktivitás során tapasztalt koordinációra és a magabiztosság-érzésre is. Mindez az élettér beszúkülésével és a jóllét, az életminőség jelentős csökkenésével, tehát a distressz, a szorongás és a lehangoltság növekedésével járhat $[17,18]$.

A szakirodalmi adatok szerint tehát az alvás és a distressz mint egy önrontó kör egymástól sem függetleníthető elemei vesznek részt a cukorbetegség kialakulásának és progressziójának szakaszaiban. Kutatásunk célja 
a stressz, az alvásproblémák és a diabetes összefüggéseinek vizsgálata felnőttek reprezentatív hazai mintáján. Hipotéziseink szerint a cukorbetegséggel élők fokozottabb stresszt élnek át, és jellemzőbb rájuk az alvásproblémák és a fáradtság, illetve energiahiány jelenléte, mint a cukorbetegséggel nem élőkre.

\section{Módszertan}

\section{Vizsgálati személyek és eljárás}

A vizsgálatba a reprezentatív Hungarostudy 2013 kutatás [19] résztvevőit vontuk be $(\mathrm{n}=2000)$. Átlagéletkoruk 46,9 év ( $\mathrm{SD}=18,24$, terjedelem: 18-91). A BMI átlaga $26,0 \mathrm{~kg} / \mathrm{m}^{2}(\mathrm{SD}=4,97$, terjedelem: $13,2-48,3)$. A minta alapadatait az 1 . táblázat tartalmazza. A vizsgálat módszertani ismérveit Susánszky és Székely [20] foglalják össze.

\section{Méröeszközök}

Szociodemográfiai adatok: rákérdeztek a válaszadók nemére, életkorára, legmagasabb iskolai végzettségére, lakóhelyére. A tápláltsági állapot megállapítására önbeszámolóval adatot gyűjtöttek a testmagasságra $(\mathrm{cm})$ és a testtömegre $(\mathrm{kg})$, ebból kiszámítottuk a BMI-t $\left(\mathrm{kg} / \mathrm{m}^{2}\right)$.

Az anyagi helyzet felmérése az alábbi kérdéssel történt. „Országos viszonylatban milyennek tartja anyagi helyzetét? Kérem, a kártyalap segítségével válaszoljon egy 1 és 10 közötti skálán! Az 1-es azt jelenti, hogy Ön országos viszonylatban nagyon rossznak tartja anyagi helyzetét, a 10-es azt jelenti, hogy nagyon jónak.”

1. táblázat |A Hungarostudy 2013 kutatás mintájának leíró adatai

\begin{tabular}{|c|c|c|}
\hline Változók & & $\mathrm{n}(\%)$ \\
\hline \multirow[t]{2}{*}{ Nem } & Férfi & $931(46,5)$ \\
\hline & Nő & $1069(53,5)$ \\
\hline \multirow[t]{4}{*}{ Lakóhely } & Budapest & $344(17,2)$ \\
\hline & Megyeszékhely & $355(17,8)$ \\
\hline & Város & $672(33,6)$ \\
\hline & Község & $628(31,4)$ \\
\hline \multirow[t]{5}{*}{ Családi állapot } & Nőtlen, hajadon & $445(22,4)$ \\
\hline & Élettárssal él & $192(9,6)$ \\
\hline & Házas & $858(43,1)$ \\
\hline & Elvált & $219(11,0)$ \\
\hline & Özvegy & $275(13,8)$ \\
\hline \multirow{3}{*}{$\begin{array}{l}\text { Iskolai } \\
\text { végzettség }\end{array}$} & Alapfokú & $1133(56,8)$ \\
\hline & Középfokú & $589(29,5)$ \\
\hline & Felsőfokú & $274(13,7)$ \\
\hline \multirow[t]{4}{*}{ BMI-kategória } & Alultáplált $(\mathrm{BMI}<18,5)$ & $69(3,6)$ \\
\hline & Normális súlyú $(\mathrm{BMI}=18,5-24,9)$ & $850(43,7)$ \\
\hline & Túlsúlyos (BMI = 25-29,9) & $642(33,0)$ \\
\hline & Elhízott (BMI $\geq 30)$ & $383(19,7)$ \\
\hline
\end{tabular}

A cukorbetegség előfordulásának felmérése egy különféle betegségeket, illetve egészségi problémákat felsoroló lista egyik elemeként történt. Ezek kapcsán arra vonatkozóan kellett válaszolni, hogy az elmúlt egy évben feküdt-e a résztvevő valamelyik felsorolt betegséggel kórházban, vagy kezelték-e járó betegként. Válaszlehetőségek: nem kezelték (1), csak járó betegként kezelték (2), feküdt kórházban is (3).

Egy tünetlista részeként felmérésre került a fáradtsággal és energiabiánnyal, illetve az alvással kapcsolatos problémák jelenléte az elmúlt hónapra vonatkozóan. Válaszlehetőségek: nem fordult elő (1), előfordult, egyáltalán nem zavart (2), előfordult, kissé zavart (3), előfordult, nagyon zavart (4).

Észlelt Stressz Kérdőiv: Az eredetileg 14 tételből álló, egyenes és fordított irányú itemeket egyaránt tartalmazó kérdőív a stressz-szint meghatározásának egyik leggyakrabban alkalmazott mérőeszköze. Azokra a gondolatokra és érzésekre kérdez rá, amelyek az adott személy stresszészlelését jellemzik, nevezetesen, hogy az elmúlt hónapban mennyi stresszhelyzetet élt át, mennyire tartja kiszámíthatatlannak, befolyásolhatatlannak, illetve túlterheltnek a mindennapjait. A válaszadás 5 fokú, Likerttípusú skálán történik a soha (0) és a nagyon gyakran (4) végpontok között. A jelen kutatásban a mérőeszköz 10 tételes változata került alkalmazásra. A magasabb pontszám nagyobb mértékü észlelt stresszt jelez [21]. A kérdőív belső megbízhatósága megfelelőnek bizonyult a mintán (Cronbach- $\alpha=0,84)$.

\section{Statisztikai elemzések}

A csoportok összehasonlítása kategoriális változók esetében $\chi^{2}$-próbával, folytonos változók esetében kétmintás t-próbával, illetve a normalitás sérülése esetében MannWhitney-féle $U$-próbával történt. A kezelt cukorbetegség, az alvásproblémák, illetve a fáradtság és energiahiány prediktorait bináris logisztikus regressziós elemzéssel teszteltük.

\section{Eredmények}

\section{A kezelt cukorbetegség elöfordulási gyakorisága}

Eredményeink szerint a válaszadók $(\mathrm{n}=1991)$ 91,8\%-át ( $\mathrm{n}=1826)$ nem kezelték az elmúlt egy évben cukorbetegséggel. A válaszadók 6,0\%-át $(\mathrm{n}=119)$ járó betegként, míg 2,3\%-át ( $\mathrm{n}=45)$ kórházban, fekvő betegként is kezelték diabetes miatt. A járó betegként, illetve kórházi betegként is kezelt cukorbetegek átlagéletkora $(Z=1,520 ; p=0,129)$ és BMI-átlaga $(t(60)=-0,594$; $\mathrm{p}=0,555)$ nem tért el szignifikánsan egymástól, ezért az elemzések során e két betegcsoportot összevontuk. Az elmúlt egy évben cukorbetegsége miatt kezelt válaszadók mintaelemszáma így 164 fő $(8,2 \%)$. 


\begin{tabular}{|c|c|c|c|c|}
\hline Változók & & $\begin{array}{l}\text { Cukorbetegséggel nem kezeltek } \\
\qquad(\mathrm{n}=1774-1827)\end{array}$ & $\begin{array}{l}\text { Cukorbetegséggel kezeltek } \\
\qquad(\mathrm{n}=160-164)\end{array}$ & $\begin{array}{l}\text { A csoportok } \\
\text { összehasonlítása }\end{array}$ \\
\hline \multirow{2}{*}{$\begin{array}{l}\text { Nem } \\
\mathrm{n}(\%)\end{array}$} & Férfiak & $864(93,6 \%)$ & $59(6,4 \%)$ & \multirow{2}{*}{$\chi^{2}(1)=7,748^{* *}$} \\
\hline & Nôk & $963(90,2 \%)$ & $105(9,8 \%)$ & \\
\hline \multirow{2}{*}{$\begin{array}{l}\text { Iskolai végzettség } \\
\text { n (\%) }\end{array}$} & Legfeljebb alapfokú & $1014(90,0 \%)$ & $113(10,0 \%)$ & \multirow{2}{*}{$\chi^{2}(1)=10,809$ ** } \\
\hline & Legalább középfokú & $809(94,1 \%)$ & $51(5,9 \%)$ & \\
\hline \multicolumn{2}{|c|}{ Életkor (év) átlaga (SD) } & $45,4(17,89)$ & $64,0(12,66)$ & $\mathrm{Z}=12,434^{* * *}$ \\
\hline \multicolumn{2}{|l|}{ BMI átlaga (SD) } & $25,7(4,77)$ & $29,4(5,75)$ & $\mathrm{t}(181)=-8,044^{* * *}$ \\
\hline \multicolumn{2}{|c|}{ Észlelt stressz átlaga (SD) } & $15,6(6,98)$ & $17,1(6,48)$ & $\mathrm{t}(1944)=-2,586^{*}$ \\
\hline
\end{tabular}

Megjegyzés: ${ }^{*} \mathrm{p}<0,05 ;{ }^{* *} \mathrm{p}<0,01 ;{ }^{*}{ }^{*} \mathrm{p}<0,001$

$\mathrm{BMI}=$ testtömegindex; $\mathrm{SD}=$ szórás

3. táblázat $\mid$ A kezelt cukorbetegség prediktorai

\begin{tabular}{lrrrrr}
\hline Magyarázó változók & $\mathrm{p}$ & $\mathrm{OR}$ & \multicolumn{1}{c}{$\mathrm{OR} \mathrm{CI}_{95}$} \\
\hline Észlelt stressz & 0,052 & 1,03 & 1,00 & 1,05 \\
\hline Nem (referencia: férfi) & 0,057 & 1,43 & 0,99 & 2,06 \\
\hline A kérdezett életkora & $<0,001$ & 1,06 & 1,05 & 1,08 \\
\hline BMI (referencia: normális súlyú & Túlsúlyos $(\mathrm{BMI}=25-29,9)$ & 0,015 & 1,80 & 1,12 & 2,88 \\
\cline { 2 - 7 }$\left.\left[\mathrm{BMI}=18,5-24,9 \mathrm{~kg} / \mathrm{m}^{2}\right]\right)$ & Elhízott $(\mathrm{BMI} \geq 30)$ & $<0,001$ & 3,02 & 1,89 & 4,82 \\
\hline Iskolai végzettség $($ referencia: legalább középfokú) & 0,575 & 0,89 & 0,61 & 1,32 \\
\hline
\end{tabular}

Megjegyzés: $n=1831$; Nagelkerke-féle $\mathrm{R}^{2}=22,1 \%$

$\mathrm{BMI}=$ testtömegindex $; \mathrm{CI}_{95}=$ 95\%-os megbízhatósági intervallum; $\mathrm{OR}=$ esélyhányados

\section{A cukorbetegséggel kezeltek jellemzöi}

Összehasonlítva az elmúlt egy évben cukorbetegséggel kezelt válaszadókat a diabetesszel nem kezelt válaszadókkal elmondható, hogy a vizsgált mintában a diabetes szignifikánsan gyakrabban fordult elő a nők, mint a férfiak körében, illetve a legfeljebb alapfokú iskolai végzettségúek esetében, mint az ennél magasabb iskolai végzettséggel bíróknál. A cukorbetegséggel kezeltek átlagos életkora, BMI-je és észlelt stressz-szintje is szignifikánsan magasabb volt, mint a cukorbetegséggel nem kezelteké (2. táblázat).

\section{Az észlelt stressz és a cukorbetegség összefüggései}

Az észlelt stressz és a diabetes összefüggését többváltozós modellben, bináris logisztikus regressziós elemzéssel is megvizsgáltuk az életkor, a nem, a tápláltsági állapot és az iskolai végzettség kontrollja mellett. Eredményeink szerint az észlelt stressz a háttérváltozók kontrollja mellett tendenciaszintü kapcsolatot mutatott a cukorbetegséggel $(\mathrm{OR}=1,03 ; \mathrm{p}=0,052)$. A modellben az idősebb életkor és a súlyfelesleg mértéke szignifikánsan megnövelte a cukorbetegség megjelenésének esélyét. A modell által megmagyarázott variancia (Nagelkerke-féle $\mathrm{R}^{2}$ ) 22,1\% (3. táblázat).

\section{A cukorbetegség és az alvásproblémák összefüggései}

$\mathrm{Az}$ elmúlt hónapra vonatkozóan alvással kapcsolatos problémák jelenlétéról a válaszadók 26,0\%-a $(\mathrm{n}=517)$ számolt be: $5,6 \%$ esetében $(\mathrm{n}=112)$ az alvásprobléma nem volt zavaró mértékú, $11,3 \%$-uk $(\mathrm{n}=224)$ kissé zavarónak, 9,1\%-uk $(\mathrm{n}=181)$ pedig nagyon zavarónak találta azokat. Fáradtság és energiahiány a válaszadók 40,2\%-ánál $(\mathrm{n}=800)$ fordult elő az elmúlt hónapban: $8,7 \%(\mathrm{n}=174)$ esetében ez nem volt zavaró, 20,4\%-uk $(\mathrm{n}=407)$ kissé zavarónak, 11,0\%-uk $(\mathrm{n}=219)$ pedig nagyon zavarónak élte meg. A további elemzésekhez a „kissé zavart” és „nagyon zavart” válaszkategóriákat összevontuk. A $\chi^{2}$-próba eredményei szerint az alvással kapcsolatos problémák jelenléte $\left(\chi^{2}(2)=61,108\right.$; $\mathrm{p}<0,001)$ és a fáradtság, illetve energiahiány érzése $\left(\chi^{2}(2)\right.$ $=51,061 ; \mathrm{p}<0,001)$ egyaránt szignifikánsan összefügg a cukorbetegséggel. Az eredmények közül kiemelendő, hogy míg az utóbbi egy évben cukorbetegséggel nem kezelt válaszadók mintegy háromnegyedénél nem fordultak elő alvással kapcsolatos problémák az elmúlt egy hónapban, addig a diabetesszel kezeltek 44\%-ánál zavaró mértékben fordultak elő. Továbbá, míg a cukorbetegséggel nem kezeltek közel kétharmada nem élte át a fáradtság és energiahiány érzését az elmúlt egy hónapban, 
addig a cukorbetegséggel kezeltek több mint felénél ez a probléma zavaró mértékben volt jelen (4. táblázat).

$\mathrm{Az}$ alvásproblémák és a fáradtság, illetve energiahiány jelenlétének prediktorait többszörös, hierarchikus bináris logisztikus regressziós elemzéssel teszteltük. Az 1. modell a kezelt cukorbetegség magyarázóerejét tesztelte. A 2. modellben kontrolláltuk az életkort, a nemet, az iskolai végzettséget és a BMI-t. A 3. modellbe beléptettük az észlelt stresszt és az anyagi helyzet önmegítélését, valamint a fáradtság, energiahiány prediktorainak tesztelése esetében az alvásproblémák jelenlétét is.

Eredményeink szerint a kezelt cukorbetegség jelenléte mintegy háromszorosára növelte az alvásproblémák megjelenésének esélyét az elmúlt egy hónapban $(\mathrm{OR}=$ 3,16; p<0,001). A cukorbetegség és az alvásproblémák kapcsolata a nem, az életkor, a BMI és az iskolai végzettség kontrollja mellett jelentősen meggyengült ugyan, azonban szignifikáns maradt $(\mathrm{OR}=1,77 ; \mathrm{p}=0,002) . \mathrm{Az}$ észlelt stressz és a szubjektív anyagi helyzet bevonása nem eredményezett lényegi változást a cukorbetegség előre jelző értékét tekintve az alvásproblémák megjele- nésére nézve $(\mathrm{OR}=1,77 ; \mathrm{p}=0,003)$. A végső modellben a kezelt cukorbetegség, a női nem, az idősebb életkor és a magasabb észlelt stressz szignifikánsan, a rosszabbnak ítélt anyagi helyzet pedig tendenciaszinten megnövelte az alvásproblémák megjelenésének esélyét. A modell által megmagyarázott variancia (Nagelkerkeféle $\mathrm{R}^{2}$ ) 24,4\% volt (5. táblázat).

A kezelt cukorbetegség ugyancsak mintegy háromszorosára növelte a fáradtság és energiahiány érzésének megjelenését az elmúlt hónapban $(\mathrm{OR}=3,26 ; \mathrm{p}<0,001)$. A nem, az életkor, a BMI és az iskolai végzettség kontrollálása ezúttal is a kezelt diabetes magyarázóerejének lényeges csökkenését eredményezte, a statisztikai szignifikancia megtartása mellett $(\mathrm{OR}=2,11 ; \mathrm{p}<0,001)$. A cukorbetegség a végső modellben is megőrizte szignifikáns prediktív erejét $(\mathrm{OR}=1,88 ; \mathrm{p}=0,004)$, amely modellben a fokozott észlelt stressz és az alvásproblémák jelenléte is kiemelt szerephez jutott a fáradtság és energiahiány előrejelzésében a női nem, az idősebb életkor és a magasabb iskolai végzettség mellett (Nagelkerke-féle $\left.\mathrm{R}^{2}=36,1 \%\right)$ (6. táblázat).

4. táblázat $\mid$ Az alvásproblémák és a fáradtság, energiahiány összefüggése a cukorbetegséggel

\begin{tabular}{|c|c|c|c|c|c|c|}
\hline \multirow[t]{2}{*}{ A tünet előfordulása } & \multicolumn{3}{|c|}{$\begin{array}{c}\text { Alvással kapcsolatos problémák } \\
\mathrm{n}(\%)\end{array}$} & \multicolumn{3}{|c|}{$\begin{array}{c}\text { Fáradtság, energiahiány } \\
\mathrm{n}(\%)\end{array}$} \\
\hline & $\begin{array}{l}\text { Cukorbetegséggel } \\
\text { nem kezeltek }\end{array}$ & $\begin{array}{c}\text { Cukorbetegséggel } \\
\text { kezeltek }\end{array}$ & Teljes minta & $\begin{array}{c}\text { Cukorbetegséggel } \\
\text { nem kezeltek }\end{array}$ & $\begin{array}{l}\text { Cukorbetegséggel } \\
\text { kezeltek }\end{array}$ & Teljes minta \\
\hline Nem fordult elő & $1386(76,1 \%)$ & $81(49,7 \%)$ & $1467(73,9 \%)$ & $1130(62,1 \%)$ & $55(33,7 \%)$ & $1185(59,7 \%)$ \\
\hline $\begin{array}{l}\text { Előfordult, és nem } \\
\text { zavarta }\end{array}$ & $101(5,5 \%)$ & $11(6,7 \%)$ & $112(5,6 \%)$ & $154(8,5 \%)$ & $20(12,3 \%)$ & $174(8,8 \%)$ \\
\hline Előfordult, és zavarta & $334(18,3 \%)$ & $71(43,6 \%)$ & $405(20,4 \%)$ & $537(29,5 \%)$ & $88(54,0 \%)$ & $625(31,5 \%)$ \\
\hline$\chi^{2}(2)$ & \multicolumn{3}{|c|}{$61,108 * * *$} & \multicolumn{3}{|c|}{$51,061 * * *$} \\
\hline
\end{tabular}

Megjegyzés: *** $\mathrm{p}<0,001$

5. táblázat |Az alvással kapcsolatos problémák prediktorai

\begin{tabular}{|c|c|c|c|c|c|c|}
\hline \multicolumn{2}{|c|}{ Magyarázó változók } & \multirow{2}{*}{$\frac{\mathrm{p}}{<0,001}$} & \multirow{2}{*}{$\frac{\mathrm{OR}}{3,16}$} & \multicolumn{2}{|c|}{$\mathrm{OR} \mathrm{CI} \mathrm{I}_{95}$} & \multirow{2}{*}{$\frac{\mathrm{R}^{2}}{3,5 \%}$} \\
\hline 1. modell & Kezelt cukorbetegség (referencia: nincs) & & & 2,25 & 4,42 & \\
\hline \multirow[t]{5}{*}{ 2. modell } & Kezelt cukorbetegség (referencia: nincs) & 0,002 & 1,77 & 1,23 & 2,55 & \multirow{5}{*}{$13,3 \%$} \\
\hline & Nem (referencia: férfi) & $<0,001$ & 1,71 & 1,37 & 2,15 & \\
\hline & Életkor & $<0,001$ & 1,03 & 1,02 & 1,04 & \\
\hline & BMI & 0,275 & 1,01 & 0,99 & 1,04 & \\
\hline & Iskolai végzettség (referencia: legalább középfokú) & 0,002 & 1,46 & 1,15 & 1,84 & \\
\hline \multirow[t]{7}{*}{ 3. modell } & Kezelt cukorbetegség (referencia: nincs) & 0,003 & 1,77 & 1,21 & 2,59 & \multirow{7}{*}{$24,4 \%$} \\
\hline & Nem (referencia: férfi) & $<0,001$ & 1,53 & 1,20 & 1,94 & \\
\hline & Életkor & $<0,001$ & 1,03 & 1,02 & 1,04 & \\
\hline & BMI & 0,403 & 1,01 & 0,99 & 1,04 & \\
\hline & Iskolai végzettség (referencia: legalább középfokú) & 0,522 & 1,09 & 0,84 & 1,41 & \\
\hline & Észlelt stressz & $<0,001$ & 1,11 & 1,09 & 1,13 & \\
\hline & Szubjektív anyagi helyzet & 0,060 & 0,94 & 0,88 & 1,00 & \\
\hline
\end{tabular}


6. táblázat |A fáradtság, illetve energiahiány prediktorai

\begin{tabular}{|c|c|c|c|c|c|c|}
\hline \multicolumn{2}{|c|}{ Magyarázó változók } & \multirow{2}{*}{$\frac{\mathrm{p}}{<0,001}$} & \multirow{2}{*}{$\frac{\mathrm{OR}}{3,26}$} & \multicolumn{2}{|c|}{$\mathrm{OR} \mathrm{CI}_{95}$} & \multirow{2}{*}{$\frac{\mathrm{R}^{2}}{3,5 \%}$} \\
\hline 1. modell & Kezelt cukorbetegség (referencia: nincs) & & & 2,29 & 4,63 & \\
\hline \multirow[t]{5}{*}{ 2. modell } & Kezelt cukorbetegség (referencia: nincs) & $<0,001$ & 2,11 & 1,46 & 3,07 & \multirow{5}{*}{$10,1 \%$} \\
\hline & Nem (referencia: férfi) & $<0,001$ & 1,88 & 1,54 & 2,30 & \\
\hline & Életkor & $<0,001$ & 1,02 & 1,01 & 1,03 & \\
\hline & BMI & 0,118 & 1,02 & 1,00 & 1,04 & \\
\hline & Iskolai végzettség (referencia: legalább középfokú) & 0,888 & 0,99 & 0,80 & 1,21 & \\
\hline \multirow[t]{8}{*}{ 3. modell } & Kezelt cukorbetegség (referencia: nincs) & 0,004 & 1,88 & 1,22 & 2,88 & \multirow{8}{*}{$36,1 \%$} \\
\hline & Nem (referencia: férfi) & $<0,001$ & 1,59 & 1,26 & 2,00 & \\
\hline & Életkor & 0,012 & 1,01 & 1,00 & 1,02 & \\
\hline & BMI & 0,248 & 1,01 & 0,99 & 1,04 & \\
\hline & Iskolai végzettség (referencia: legalább középfokú) & 0,004 & 0,70 & 0,54 & 0,89 & \\
\hline & Észlelt stressz & $<0,001$ & 1,08 & 1,06 & 1,10 & \\
\hline & Szubjektív anyagi helyzet & 0,954 & 1,00 & 0,94 & 1,06 & \\
\hline & $\begin{array}{l}\text { Alvásprobléma az elmúlt egy hónapban } \\
\text { (referencia: nem fordult elő) }\end{array}$ & $<0,001$ & 7,94 & 6,03 & 10,46 & \\
\hline
\end{tabular}

\section{Megbeszélés}

A diabetes egyre nagyobb ütemben növekvő előfordulási gyakorisága az egyik legnagyobb egészségügyi kihívást jelenti az egész világon. A jelentôs egészség- és életminőség-romlással járó betegség nem pusztán az egyén, de az egyes országok gazdasága számára is megterhelő egyfelől a munkaképes korúak munkaképtelenné válása miatt, másfelól pedig azért, mert a cukorbetegség és szövődményeinek kezelése az egészségügyi ellátórendszer szinte minden szintjét és területét igénybe veszi [1]. Mivel a világban érvényesülő tendenciák hazánkban is tetten érhetók, a 2 -es típusú diabetes mellitus prevalenciájának utóbbi években megfigyelt rapid növekedése Magyarországon is a népegészségügyi krízisállapot lehetőségére hívja fel a figyelmet [2].

Ugyan a 2-es típusú cukorbetegség kialakulásáért a szintén világméretû́ problémát jelentő elhízás tehető felelőssé, az elmúlt évek kutatási eredményei szerint maga az elhízás számos civilizációs ártalommal függ össze. Erre példa az alvásmennyiségnek és -minőségnek a munkaórák kitolódása miatti változása [5-6], illetve a szorongásszint növekedése $[9,11]$. A szakirodalom alapján tehát az egyén felelőssé tételéról a társadalmi változások azonosítása és kezelése irányába tolódott a betegség alakulásának megértése, megelőzése és ellátása.

E tendenciáknak megfelelően kutatásunk célja a stressz, az alvásproblémák és a diabetes összefüggéseinek vizsgálata volt a reprezentatív Hungarostudy 2013 kutatás [19] felnőtt hazai mintáján. Eredményeink szerint a kezelt cukorbetegséggel élők körében fokozottabb az észlelt stressz szintje, továbbá a cukorbetegség az alvásproblémáknak, illetve a fáradtságnak és energiahiánynak az észlelt stressztől és a többi potenciális háttérváltozó- tól (mint amilyen például az életkor, a BMI, a nem vagy a szocioökonómiai státusz) független prediktora. Az észlelt stressz szintjének a cukorbetegek körében megjelenő nagyobb mértéke megfelel a nemzetközi szakirodalmi adatoknak [13], illetve nem meglepö, tekintve, hogy a szorongásszint a betegség etiológájában is szerepet kaphat [11], rontja a már kialakult betegség kezelésével való együttmúködést [16], emellett az egyre fokozódó szövődmények következménye is lehet [17-18]. Ugyanígy, az alvás a cukorbetegség mindhárom fázisában: a létrejöttében [5,22], a kezelésében és a már szövődményekkel terhelt időszakban egyaránt szerepet kaphat [17].

Eredményeink tehát aláhúzzák a kielégítő alvás és a stressz-szint, a stresszkezelés monitorozásának fontosságát a még egészséges populációban, a diabetes (és más betegségek) prevenciója szempontjából, illetve felhívják a figyelmet arra, hogy a már kialakult betegséggel élő személy ellátása során mind az alvásminőség és -mennyiség, mind a szorongásszint ellenőrzése és a betegek támogatása elengedhetetlen. A szorongás csökkentése és az alváshigiénés tanácsadás már alacsony intenzitású pszichológiai intervenciókkal is megvalósítható a mindennapi orvosi gyakorlatban [23]. Továbbá, mivel a diabetes önmenedzselését a pszichoszociális stresszorok és az azokkal való elégtelen megküzdés jelentősen megnehezítheti, érdemes lenne a diabetesedukációs programoknak és a diabetesszel élők gondozásának a szerves részévé tenni a stresszkezelési készségek fejlesztését [24]. Az utóbbi évtizedekben megalapozottá vált az a feltételezés is, miszerint a diabetesszel összefüggő distressz (amelyet elkülönítenek az esetenként jellemző klinikailag jelentôs depressziótól) jelentős, negatív hatást gyakorol a betegek életminőségére és adherenciájára [25], ezért első lépésként ennek szürése, majd kezelése hazánkban is 
szükséges lenne, ahogy az alvásprobléma azonosítása és kezelése is. Különös tekintettel arra, hogy mindkét problémakör kezelésére elérhetők [26], illetve várhatóan a közeljövőben elérhetővé válnak [27] hatékony magatartásorvoslási módszerek.

A vizsgálat legfőbb korlátját a keresztmetszeti kutatási elrendezés képezi, amely nem ad lehetőséget az ok-okozati következtetések levonására. Ugyanakkor, mivel a vizsgált jelenségek között cirkuláris okság feltételezhető, az együttjárások alátámasztása is lényegi üzeneteket közvetíthet a cukorbetegséggel élők kezelését végzők számára. Az adatfelvétel során nem tettek különbséget l-es és 2-es típusú diabetes között, emellett kizárólag a kezelt cukorbetegségre kérdeztek rá, így elképzelhető, hogy az ebből a szempontból egészségesnek tekintett mintarészben előfordulnak kezeletlen cukorbetegséggel élők, illetve olyan egyének, akik nem is tudnak a cukorbetegségükről. A testtömegre és a testmagasságra vonatkozóan is csak önbeszámolóval nyert adatok állnak rendelkezésre, amelyek érvényessége kérdéses lehet. Mindez óvatosságra int az eredmények értelmezésével és általánosíthatóságával kapcsolatban. Megjegyezzük továbbá, hogy bár a fáradtság és energiahiány a cukorbetegek körében gyakoribb alvásprobléma következménye is lehet, az l-es típusú cukorbetegségben gyakoribb hypoglykaemiás epizódokkal is magyarázható lehet a vizsgálati eredményekben megjelenő nagyobb arányú fáradékonyság és energiahiány. További módszertani korlát, hogy a kezelt cukorbetegséggel élők átlagéletkora jelentősen magasabb, mint a cukorbetegséggel nem kezelteké. Ezt a problémát úgy próbáltuk orvosolni, hogy a többváltozós elemzések során minden esetben kontrolláltuk az életkort. Végül a diabetes miatt kezelésben részesültek relatíve kicsi elemszáma miatt egyes elemzések esetében csökkent a statisztikai erő.

A vizsgálat korlátai ellenére eredményeink felhívják a figyelmet arra, hogy mind az észlelt stressz, mind az alvásproblémák a magyarországi cukorbetegséggel élő populáció számára is számottevő jelentőségúek. Mivel a szakirodalmi adatok tükrében mindkét tényező szerepet kaphat a betegség kialakulásában és lefolyásában is $[11,13,14$, 17], az eredmények értelmében a mentális megbetegedéshez is hozzájáruló stressz-szint, distresszérzés és alvászavar szûrésére és kezelésére szükséges a hazai klinikai gyakorlatban is figyelmet fordítani. Az utóbbira az Amerikai és az Európai Diabetes Társaság (American Diabetes Associaton; European Association for the Study of Diabetes) 2018-as, közösen megfogalmazott ajánlása is kitér: hangsúlyozza a krónikus mentális betegség diagnosztizálásának, szürésének és kezelésének fontosságát [28].

Anyagi támogatás: A közlemény megírása nem részesült anyagi támogatásban.

Szerzői munkamegosztás: V. Á.: Szakirodalom-kutatás, az elméleti bevezető és a megbeszélés megszövegezése.
K. L.: Szakirodalom-kutatás, az elméleti bevezető megszövegezése. Cz. E.: Adatelemzés, az eredmények leírása, a megbeszélés megszövegezése. A kézirat végső változatának elkészítése a három szerző közös munkájának eredménye.

Érdekeltségek: A szerzőknek nincsenek érdekeltségeik.

\section{Irodalom}

[1] Ogurtsova K, da Rocha Fernandes JD, Huang Y, et al. IDF Diabetes Atlas: global estimates for the prevalence of diabetes for 2015 and 2040. Diabetes Res Clin Pract. 2017; 128: 40-50.

[2] Domján BA, Ferencz V, Tänczer T, et al. Large increase in the prevalence of self-reported diabetes based on a nationally representative survey in Hungary. Prim Care Diabetes 2017; 11: 107111.

[3] Shen H, Zhao J, Liu Y, et al. Interactions between and shared molecular mechanisms of diabetic peripheral neuropathy and obstructive sleep apnea in type 2 diabetes patients. J Diabetes Res. 2018; 2018: 3458615 .

[4] Chaput JP, McNeil J, Després JP, et al. Short sleep duration as a risk factor for the development of the metabolic syndrome in adults. Prev Med. 2013; 57: 872-877.

[5] Itani O, Jike M, Watanabe N, et al. Short sleep duration and health outcomes: a systematic review, meta-analysis, and metaregression. Sleep Med. 2017; 32: 246-256.

[6] Jike $\mathrm{M}$, Itani $\mathrm{O}$, Watanabe $\mathrm{N}$, et al. Long sleep duration and health outcomes: a systematic review, meta-analysis and metaregression. Sleep Med Rev. 2018; 39: 25-36.

[7] Grandner MA, Drummond SP. Who are the long sleepers? Towards an understanding of the mortality relationship. Sleep Med Rev. 2007; 11: 341-360.

[8] Larcher S, Benhamou PY, Pépin JL, et al. Sleep habits and diabetes. Diabetes Metab. 2015; 41: 263-271.

[9] Rains JL, Jain SK. Oxidative stress, insulin signaling, and diabetes. Free Radic Biol Med. 2011; 50: 567-575.

[10] Anderson KN, Bradley AJ. Sleep disturbance in mental health problems and neurodegenerative disease. Nat Sci Sleep 2013; 5: 61-75.

[11] van der Valk ES, Savas M, van Rossum EF. Stress and obesity: are there more susceptible individuals? Curr Obes Rep. 2018; 7: 193-203.

[12] Sal I, Papp I, Perczel Forintos D. Possibilities of behavioral therapy in diabetes mellitus and obesity. [Magatartás-orvoslási lehetőségek a cukorbetegség és az elhízás kezelésében.] Orv Hetil. 2012; 153: 410-417.

[13] Bickett A, Tapp H. Anxiety and diabetes: innovative approaches to management in primary care. Exp Biol Med (Maywood). 2016; 241: 1724-1731.

[14] Perrin NE, Davies MJ, Robertson N, et al. The prevalence of diabetes-specific emotional distress in people with type 2 diabetes: a systematic review and meta-analysis. Diabet Med. 2017; 34: 1508-1520.

[15] Sal I, Susánszky É, Papp I. Quality of life in diabetes mellitus assessed on the basis of Hungarostudy Health Panel survey. [Cukorbetegek életminősége a Hungarostudy Egészség Panel vizsgálat alapján.] Orv Hetil. 2013; 154: 531-537.

[16] DiMatteo MR, Lepper HS, Croghan TW. Depression is a risk factor for noncompliance with medical treatment: meta-analysis of the effects of anxiety and depression on patient adherence. Arch Intern Med. 2000; 160: 2101-2107.

[17] Bouhassira D, Letanoux M, Hartemann A. Chronic pain with neuropathic characteristics in diabetic patients: a French crosssectional study. PLoS ONE 2013; 8: e74195.

[18] Brod M, Blum SI, Bushnell DM, et al. Development and validation of the Diabetic Peripheral Neuropathic Pain Impact 
(DPNPI) measure, a patient-reported outcome measure. Qual Life Res. 2015; 24: 3001-3014.

[19] Susánszky É, Szántó Zs. (eds.) Hungarian state of mind 2013. [Magyar lelkiállapot 2013.] Semmelweis Kiadó, Budapest, 2013. [Hungarian]

[20] Susánszky É, Székely A. Methodology of Hungarostudy 2013 Survey. In: Susánszky É, Szántó Zs. (eds.) Hungarian state of mind 2013. [A Hungarostudy 2013 felmérés módszertana. In: Susánszky É, Szántó Zs. (szerk.) Magyar lelkiállapot 2013.] Semmelweis Kiadó, Budapest, 2013; pp. 13-21. [Hungarian]

[21] Stauder A, Konkolÿ Thege B. Characteristics of the Hungarian version of the Perceived Stress Scale (PSS). [Az Észlelt Stressz Kérdőív (PSS) magyar verziójának jellemzői.] Mentálhig Pszichoszom. 2006; 7: 203-216. [Hungarian]

[22] Lee SW, Ng KY, Chin WK. The impact of sleep amount and sleep quality on glycemic control in type 2 diabetes: a systematic review and meta-analysis. Sleep Med Rev. 2017; 31: 91-101.

[23] Purebl Gy. Low intensity psychological interventions in everyday medical practice. [Alacsony intenzitású pszichológiai intervenciók a mindennapi orvosi gyakorlatban.] Oriold és Társai Kiadó, Budapest, 2018. [Hungarian]

[24] Zamani-Alavijeh F, Araban M, Koohestani HR, et al. The effec tiveness of stress management training on blood glucose control in patients with type 2 diabetes. Diabetol Metab Syndr. 2018; 10: 39 .

[25] Fisher L, Mullan JT, Arean P, et al. Diabetes distress but not clinical depression or depressive symptoms is associated with glycemic control in both cross-sectional and longitudinal analyses. Diabetes Care 2010; 33: 23-28.

[26] Pöpel A. Evidence-based treatment of insomnia. [Evidenzbasierte Behandlung nicht-organischer Schlafstörungen.] Praxis (Bern 1994) 2018; 107: 1339-1343. [German]

[27] Chima CC, Salemi JL, Sidani MA, et al. Coaching and education for diabetes distress (CEDD): protocol for a randomized controlled trial. JMIR Res Protoc. 2019; 8: e12166.

[28] Davies MJ, D'Alessio DA, Fradkin J, et al. Management of hyperglycaemia in type 2 diabetes, 2018. A consensus report by the American Diabetes Association (ADA) and the European Association for the Study of Diabetes (EASD). Diabetologia 2018; 61: 2461-2498.

(Czeglédi Edit dr., Budapest, Üllői út 26., 1085 e-mail: czegledi.edit@med.semmelweis-univ.hu)

\section{PÁLYÁZAT}

A Prof. Dr. Romics László Akadémikus Emlékére Alapítvány pályázatot hirdet Magyarországon dolgozó, magyar állampolgárságú, 40 éven aluli orvosok és orvosbiológiai kutatással foglalkozó személyek számára. A nyertes pályázó(k) között 500000 Ft alapítványi adomány kerül kiosztásra.

A pályázat célja: a klinikai gyógyítás vagy orvosi tudományos kutatás területén dolgozók kiemelkedő tudományos tevékenységének elismerése.

Előnyt élveznek azok a pályázók, akik az alapítvány névadójának munkásságát folytatva cardiovascularis és anyagcsere-betegségek területéről nyújtanak be pályázatot.

A pályázat benyújtásának határideje: 2020. január 31. (elbírálásának határideje: 2020. április 30.)

A pályázatot a palyazat@romicsalapitvany.hu e-mail címre pdf formátumban kell benyújtani.

A pályázatot természetes személy, saját nevében, magyar nyelven nyújthatja be, a pályázati anyag ábrák nélkül maximum 15000 leütés (karakter) terjedelmü lehet. A pályázathoz mellékelni kell egy rövid szakmai életrajzot a születési év megjelölésével.

A pályázat benyújtását saját kézzel aláírt és dátummal ellátott levélben kell bejelenteni az alapítvány titkárának címezve (a borítékra írandó cím: dr. Dudás Márta, 1461 Budapest, Pf. 62) könyvelt (ajánlott) küldeményben, mert ezen bejelentés alapján válik hitelessé a pályázat. A pályázatot nyomtatott formában nem kell mellékelni.

Az alapítvány adatairól, müködéséről a www.romicsalapitvany.hu honlapon található információ.

A cikk a Creative Commons Attribution 4.0 International License (https://creativecommons.org/licenses/by/4.0/) feltételei szerint publikált Open Access közlemény, melynek szellemében a cikk bármilyen médiumban szabadon felhasználható, megosztható és újraközölhető, feltéve, hogy az eredeti szerző és a közlés helye, illetve a CC License linkje és az esetlegesen végrehajtott módositások feltüntetésre kerülnek. (SID_1) 